O AUTOR

\title{
Carlos Drummond de Andrade
}

(1902-1987) Poeta, cronista, contista e tradutor. Publicou, entre muitos outros: Alguma poesia (1930); Brejo das almas (1934); Sentimento do mundo (1940); A rosa do povo (1945); Passeios na ilha; e Viola de bolso (1952); Versiprosa; José \& outros; Uma pedra no meio do caminho (1967); Caminhos de João Brandão (1970); Amor, amores (1975); Esquecer para lembrar (1979); Contos plausíveis (1981); Amar se aprende amando (1985); Tempo, vida, poesia (1986).

\section{OS OMBROS SUPORTAM $\mathrm{O}_{\mathrm{MUNDO}}{ }^{1}$}

Chega um tempo em que não se diz mais: meu Deus.

Tempo de absoluta depuração.

Tempo em que não se diz mais: meu amor.

Porque o amor resultou inútil.

E os olhos não choram.

$\mathrm{E}$ as mãos tecem apenas o rude trabalho.

E o coração está seco.

Em vão mulheres batem à porta, não abrirás.

Ficaste sozinho, a luz apagou-se, mas na sombra teus olhos resplandecem enormes.

És todo certeza, já não sabes sofrer.

E nada esperas de teus amigos.

Pouco importa venha a velhice, que é a velhice?

Teus ombros suportam o mundo e ele não pesa mais que a mão de uma criança.

As guerras, as fomes, as discussões dentro dos edifícios provam apenas que a vida prossegue e nem todos se libertaram ainda.

Alguns, achando bárbaro o espetáculo, prefeririam (os delicados) morrer.

Chegou um tempo em que não adianta morrer.

Chegou um tempo em que a vida é uma ordem.

A vida apenas, sem mistificação. 


\section{MÃOS DADAS ${ }^{2}$}

Não serei o poeta de um mundo caduco.

Também não cantarei o mundo futuro.

Estou preso à vida e olho meus companheiros.

Estão taciturnos mas nutrem grandes esperanças.

Entre eles, considero a enorme realidade.

O presente é tão grande, não nos afastemos.

Não nos afastemos muito, vamos de mãos dadas.

Não serei o cantor de uma mulher, de uma história, não direi os suspiros ao anoitecer, a paisagem vista da janela, não distribuirei entorpecentes ou cartas de suicida, não fugirei para as ilhas nem serei raptado por serafins.

O tempo é a minha matéria, o tempo presente, os homens presentes, a vida presente. 